\title{
NA ROTA DOS CABOCLOS ${ }^{1}$
}

\author{
Miriam C. M. Rabelo ${ }^{2}$ \\ Clara Flaksman ${ }^{3}$
}

Resumo: Presentes em muitas religióes de matriz afroindígena, caboclos são entidades plásticas, que escapam a definiçóes precisas e se destacam pelo seu movimento. Levando a sério essa propensão dos caboclos ao movimento, este texto evita perguntas relativas à origem ou natureza dessas entidades em favor de uma abordagem que acompanha seus trajetos, buscando identificar os efeitos de suas passagens pelas vidas das pessoas e terreiros baianos onde atuam. Conforme mostra, nas casas em que têm papel de destaque, os caboclos performam uma topologia móvel que aproxima e junta de maneiras variáveis tempos, paisagens e práticas diversas. No seu movimento, os caboclos ajudam a compor o terreiro como espaço em que novas conexóes podem se produzir. Se o resultado dessa composiçáo pode ser chamado de mistura, é importante ressaltar que o sentido de mistura aqui é social: remete à possibilidade de convivência entre seres diferentes.

Palavras-chave: Caboclos; Religióes Afroindígenas; Movimento; Trajetórias.

${ }^{1}$ Como citar: RABELO, Miriam; FLAKSMAN, Clara. Na rota dos caboclos. Debates do NER, Porto Alegre, v. 2, n. 38, p. 145 - 180, 2020.

2 Doutora em Ciências Sociaia/Antropologia pela University of Liverpool, LIVERPOOL, Inglaterra. Atualmente é professora titular do Departamento de Sociologia e do Programa de Pós-Graduação em Ciências Sociais da Universidade Federal da Bahia, Brasil. E-mail: mcmrabelo@uol.com.br.

${ }^{3}$ Doutora em Antropologia Social pela Universidade Federal do Rio de Janeiro, Brasil. Atualmente realiza pós-doutorado (Faperj) no Programa de Pós-Graduaçáo em Antropologia Social do Museu Nacional/Universidade Federal do Rio de Janeiro, Brasil. E-mail: claramflaksman@gmail.com.

Debates do NER, Porto Alegre, ano 20, N. 38, P. I45-i 80, Ago./Dez. 2020 


\begin{abstract}
Present in many different Afroindigenous religions of Brazil, caboclos are plastic entities that escape precise definitions and stand out for their movement. Taking seriously the caboclos's inclination toward movement, this text avoids questions regarding their origin or nature, in favor of an approach that accompanies their journeys, seeking to identify the effects of their passage through the lives of the people and houses (terreiros) where they act. It argues that in the terreiros where they play a prominent role, caboclos perform a mobile topology that brings together in variable ways different times, landscapes, and practices. In their movement, the caboclos help to compose the terreiro as a space where new connections can always be produced. If the result of this composition is a mixture, it is important to emphasize that the sense of mixing here is social: it refers to the possibility of different beings mingling and living together.
\end{abstract}

Keywords: Caboclos; Afroindigenous religions; Movement; Trajectories.

\title{
CHEGANDO
}

Caboclos são entidades em movimento, que habitam paragens distantes, de onde chegam ou irrompem em meio a galopes, saltos, cambaleios. Ao se fazerem presentes, arrastam consigo pedaços de seus mundos, atraindo espectadores que não tardam a ser puxados para dentro, para sambar com eles e, quem sabe, dar lugar a mais um deles. Quando se juntam para dançar (ou "vadiar"), mar, sertão e mato muitas vezes se justapóem, quase se tocando. Vêm de suas aldeias para trabalhar, mas também beber, fumar e prosear. $\mathrm{O}$ vínculo com eles pode durar o tempo de uma vida, mas também pode ser subitamente desfeito. E quando partem de vez, tendo cumprido sua missão, deixam órfãos não só seus filhos ou médiuns, mas também clientes, amigos, confidentes e companheiros de farra. São entidades plásticas - parecem integrar-se ou adaptar-se a qualquer situação. Estão presentes no candomblé, na umbanda e no espiritismo, em locais públicos e espaços domésticos, 
sejam eles espaços religiosos ou não. Convivem com os orixás e com espíritos desencarnados e, da mesma forma, como alguns preferem cantigas e rezas, outros gostam mesmo é de sambar, beber, fumar charutos, e há ainda aqueles que apreciam as duas coisas. Sua mobilidade e plasticidade fazem deles mediadores por excelência, conectando tempos e paisagens, práticas e entidades diferentes.

Neste texto, ao invés de propor uma definição dos caboclos - juntando alguns de seus atributos mais salientes, em uma perspectiva essencialista queremos tratar de algumas dimensóes do seu movimento. $\mathrm{Na}$ verdade, tendo percebido a dificuldade de responder à pergunta "o que ou quem são mesmo os caboclos ? ?", decidimos nos aproximar dessas entidades acompanhando seus trajetos, encontrando os efeitos de suas passagens pelas vidas das pessoas e terreiros onde atuam. Mais do que desvendar a "origem" ou a "natureza" do caboclo, pretendemos traçar os seus caminhos (termo que no candomblé significa tanto trajetória percorrida quanto destino) e lançar luz sobre sua multiplicidade.

Nosso material vem de fontes diversas: de nosso próprio trabalho etnográfico, de trabalhos de outros pesquisadores das religióes de matriz africana e de depoimentos públicos de lideranças. Com poucas exceçóes tratamos aqui de terreiros baianos em que o culto aos caboclos ocupa lugar de destaque, a maioria deles na região do Recôncavo Baiano onde iniciamos

${ }^{4}$ Não deixando de levar em conta, em primeiro lugar, a polissemia do termo: "caboclo" tem uma ampla variedade de significados. Inicialmente, podemos traçar a distinçáo mais evidente: refere-se tanto a pessoas quanto a entidades espirituais. Dentro dessa primeira variação, há outras diferenciaçóes, referentes aos tipos de seres (tanto pessoas quanto entidades) que são denominados "caboclos". O caboclo ao qual nos referimos aqui é a denominação utilizada para uma ampla gama de entidades espirituais, cultuadas em diversas naçóes do candomblé da Bahia. Encontram-se, sob essa nomenclatura, tanto espíritos de índios quanto de boiadeiros, marinheiros e assim por diante, como veremos ao longo deste trabalho. 
pesquisa ${ }^{5}$, mas também um terreiro na Chapada Diamantina, no interior do estado, pesquisado por uma de nós em finais dos anos 1980 (Rabelo, 1990).

\section{CAMINHOS}

Em geral, os caboclos chegam na vida (e no corpo) das pessoas para trabalhar - curar, aconselhar, resolver problemas de toda sorte. Muitos se referem a seu trabalho como uma missão - o caminho (destino/percurso) de um caboclo é sua missão - e é o tempo da missão que determina sua permanência. Uma vez que baixam, tendem a acompanhar seus filhos por toda vida. Mas assim como chegam, podem bem partir. E se seus filhos porventura morrem antes que tenham completado sua missão, podem bem procurar outros (corpos) humanos para trabalhar. Vejamos alguns desses percursos nas casas e nos corpos de algumas pessoas.

Roquinha é mãe de santo de uma casa de candomblé de Salvador. Passou muitos anos na umbanda, antes de se aproximar do candomblé. No centro de umbanda que frequentava recebia o caboclo Boiadeiro que trabalhava na mesa branca e dava consulta regularmente. Uma doença grave a conduziu para o candomblé. Ela foi feita (iniciada) no candomblé e depois de um longo percurso recebeu o cargo de mãe de santo. Boiadeiro é hoje presença constante no seu terreiro. A vinda do caboclo para o candomblé foi negociada: para que ficasse no terreiro, seria preciso que lhe permitissem atuar na mesa branca. Trabalhar por caridade, ajudando aos necessitados, era a missão que tinha a cumprir na terra. Boiadeiro não queria (e não quer) parte com as coisas de candomblé. Atualmente preside as sessôes de mesa branca, realizadas quinzenalmente no terreiro.

\footnotetext{
${ }^{5}$ Nos referimos aqui aos projetos associados "Na rota dos caboclos", que contou com o apoio do PPGCS-UFBA e "Caminhos e Moradas dos Caboclos na Bahia" desenvolvido com apoio do CNPq.
}

Debates do NER, Porto Alegre, ano 20, N. 38, P. I45-I80, Ago./Dez. 2020 
Nas sessóes, uma grande mesa é transportada para o centro do barracão. Forrada com uma toalha branca, a mesa abriga uma profusão de objetos: pipocas espalhadas por toda sua extensão, velas, vasos com flores, charutos, bebidas para os caboclos, imagens de santos: Cosme e Damião, Santa Bárbara, São Jorge e a Virgem Maria. Quando começa a sessão a mãe de santo e os filhos da casa sentam-se em volta da mesa. Atrás deles, de pé, distribuem-se os demais participantes, em sua maioria clientes. A sessão começa com reza. Um Pai Nosso é entoado para cada um dos clientes que antecipadamente deixou seu nome com a equede responsável pela organizaçáo do evento. Quando termina a longa lista de clientes, os caboclos começam a chegar, embalados pelas rezas, que ainda não cessaram. Alguns vêm de forma violenta derrubando seus médiuns dos banquinhos. Mas a ordem não demora a ser restabelecida para mais uma rodada de oraçóes: Ave-Marias e Salve Rainhas. Ao final, todos levantam e dão-se as mãos, formando um grande círculo - membros da assistência incluídos. Cantigas de caboclo, então, sucedem as rezas. Os caboclos se desprendem do círculo e logo recebem folhas para dar passe. Entre eles está Boiadeiro - o mais procurado pelos presentes, que fazem fila para serem atendidos. Muitos conversam com o caboclo, contando-lhe seus problemas e pedindo conselhos; quando é necessário, uma equede toma nota das receitas que ele prescreve. No bairro, Boiadeiro tem fama de curador caridoso e eficiente.

Paulo vive no município de Sapeaçu, em zona de sítios, mais recuada da cidade. No seu sítio, muitas árvores fazem sombra na área central de terra batida onde estão sua residência e o terreiro - classificada como "giro de caboclo", conforme documento da Fenacab ${ }^{6}$ emoldurado na parede do barracão. Sentamo-nos para conversar debaixo de uma mangueira, de frente para um barranco que margeia o terreno de Paulo.

6 Federação Nacional do Culto Afro-Brasileiro, entidade responsável por expedir alvarás de funcionamento para casas filiadas e manter o registro das suas atividades religiosas.

Debates do NER, Porto Alegre, ano 20, N. 38, P. I45-i 80, Ago./Dez. 2020 
Paulo conta que tinha 17 anos quando um caboclo lhe pegou pela primeira vez. Era Gentio.

Ele me pegou e desceu essa mata aqui. Aqui é o lugar chamado "represa". Ali embaixo, depois daquela mata ali embaixo é água. Dá $2 \mathrm{~km}$ de água aí. Ele me pegou, atravessou esta água aí, caiu na mata aí, levou três dias dentro pelo mato. Sem roupa, sem lençol, sem nada. Três dias perdido no mato. Aí minha máe foi na casa de um rezador e o rezador disse que eu estava na mata, que o caboclo estava comigo. Aí foi, o homem fez o trabalho, chamou, ele veio. Todo lascado... aí teve que cuidar. [Ele disse] que minha sina era trabalhar, ajudar o povo. Eu que resolvesse. Se eu não quisesse tinha outra solução pra mim, mas eu como não queria perder minha vida, né?

Depois de alguns anos, o rezador que havia sido capaz de controlar o caboclo de Paulo, e que cuidara dele, veio a falecer. Desprotegido, Paulo experimentou novo período de sofrimento. Resolveu, então, procurar outra pessoa que pudesse tomar conta do seu caboclo. Foi ao encontro de um amigo rezador que trabalhava com o caboclo Sultão das Matas. Ao vê-lo, Sultão disse que não poderia cuidar dele. "Mas não se incomode não, que eu tenho um lugar para lhe levar". Conduziu-o então a casa de dona Maria.

Maria Bacelar, que veio a ser a mãe de santo de Paulo por dezenove anos, era uma personagem famosa da vida religiosa e política de Irará, município situado a uns $140 \mathrm{~km}$ de Sapeaçu, em região conhecida como porta do sertão da Bahia. Além de mãe de santo era vereadora influente e diretora de uma escola municipal que funcionava em sua fazenda, junto com o terreiro de umbanda. A festa do caboclo Eru, seu guia espiritual, era evento importante da cidade. Quando D. Maria estava perto de morrer, Paulo sonhou com ela lhe chamando para dar um presente a Oxum. Foi encontrá-la em Irará:

Eu saí tấo cedo, quando eu cheguei lá ela estava rezando o terço na frente da porta. Ela me olhou assim, mandou eu aguardar. Ela terminou de fazer as oraçóes dela. Depois ela me chamou. Eu disse: "Ó, veia, eu tive um sonho assim, assim, assim". Ela disse: "Eu sei, meu filho, você não está aqui à toa 
não. Você está aqui porque Eru que lhe trouxe". Eru era o caboclo dela. E aí na hora que ela falou que foi Eru que me trouxe, ele bafou ela. Bafou ela e me abraçou, e aí caiu a lágrima e caiu a lágrima e aí ele me disse: "É, meu filho, só você que vai continuar o que eu quero". "Sobre?" "É, a velha Maria está indo embora". Aí chora ele, chora eu, chora ele, chora eu. E ele disse: "Olhe, ninguém tem o que você tem, quem anda aqui na minha casa. Continue o que eu lhe ensinei que ninguém vai poder com você. Lembre de mim aonde você for". Aí aquilo ficou na minha cabeça.

Mas mesmo com o recado de Eru, Paulo não assumiu o lugar de D. Maria depois de sua morte - nem nenhum de seus filhos. O terreiro permaneceu sem liderança, e depois de algum tempo Eru veio para expressar seu descontentamento - no corpo da filha de Paulo.

Ele [Eru] pegou a minha filha dormindo, e botou aí no meio da sala e largou a língua no que ele queria. [Falou] dos filhos de dona Maria que abandonou. Ela tem casa em Cabuçu, abandonada, o terreiro lá dela de Irará os filhos abandonaram. Então o caboclo está numa revolta muito grande, só que eu não tenho como resolver, tu tá entendendo? Eu não tenho como resolver. $\mathrm{O}$ que eu posso resolver é alimentar ele. E ele, espiritualmente, ele resolva da maneira deles, porque eu não posso ir lá dizer aos filhos de dona Maria que isso não está bom, que isso está errado. Eu não posso fazer isso, porque eles tinham que ter a noção que o que ela deixou tinha que continuar, né?

$\mathrm{Na}$ sua filha, Paulo vê a continuidade de seu trabalho e, embora não pareça muito disposto a falar sobre isso, também a volta do caboclo Eru de dona Maria. Se o corpinho franzino da menina de doze anos desponta agora como lugar escolhido por Eru para seguir trabalhando, Paulo bem sabe que, assim que a notícia se espalhar, esse lugar será contestado pelos outros filhos da mãe-de-santo vereadora. Mas também sabe que os caboclos escolhem e fazem seus caminhos. Foi assim com ele: jogado na mata por Gentio, foi levado a experimentar no corpo não só a energia do caboclo, mas também seu elemento. Quando precisou de alguém para cuidar dele e de seus guias, foi Sultão das Matas - o caboclo de um amigo rezador - que o conduziu 
àcasa de dona Maria. E foi Eru que o reconduziu a Irará, quando sua mãe de santo estava prestes a morrer.

Toinho foi criado por Dona Nilza, mãe de santo de uma casa de umbanda em um bairro da periferia de Santo Amaro, cidade próxima de Sapeaçu. Já muito idosa e doente, ela não dá mais sessão e as famosas festas de caboclo que animavam sua casa são agora lembranças do passado.

Foi uma filha de dona Nilza que nos encaminhou para a casa de Toinho - "ele vai saber explicar tudo pra vocês". É uma casa modesta com varanda na frente em uma rua de casas geminadas, muito diferente da paisagem rural do terreiro de Paulo. Entramos direto no que parece ser o barracão, nossa impressáo confirmada pelas prateleiras com imagens de santos e quadros religiosos nas paredes: Mãe d'Água, Preto Velho, Caboclo Mata Virgem.

Figura 1- Pôster de Mata Virgem no terreiro de Toinho (foto de Antônia Oliveira, 2018)

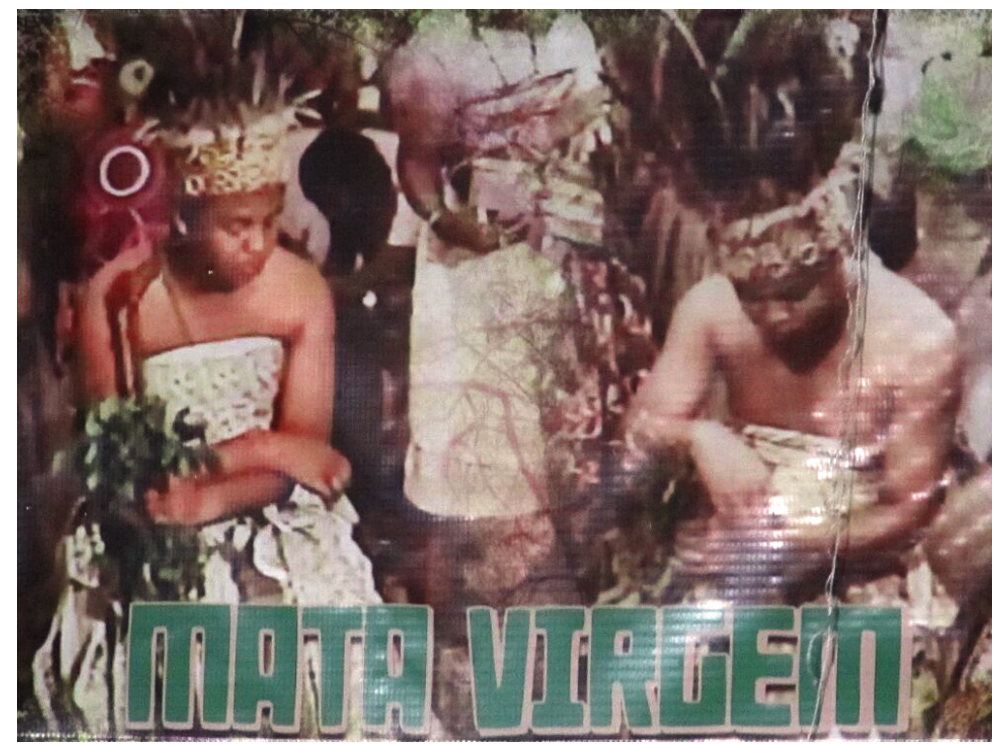


Toinho entáo nos contou a história de dona Nilza:

Hoje mãe está com 85 anos, ela é de Oxalá com Oxum, ela trabalha com o caboclo Rei das Estrelas que foi batizado por Rei de Congo e Rei José. As histórias de caboclo lá são muito profundas. Porque mãe quando começava rezar a cabana, ela começava a rezar as treze noites para Santo Antônio, quando chegava no dia 14 ela começava a vestir os índios. Quando era o dia primeiro de julho, ela armava a cabana. Era a cabana maior que existia em Santo Amaro. Começava em julho e terminava no último sábado de setembro. Todo dia se referenciava ali, ali todo dia se cantava, ali todo dia se louvava. Quando as frutas iam ficando ruins, eram retiradas e colocadas nas águas, no mato, até completar a cabana. A cabana era de Campo Verde, caboclo Campo Verde. Sendo que o caboclo da casa, o patrono, o nosso rei, era o Rei das Estrelas. Só que ela também tinha outro espírito que trabalhava de dia (sexta-feira) que chama Doutor Antônio Manuel da Luz, é um médico. Esse fez muita caridade, fez muitas ações, tem provas vivas ainda, graças a Deus. E aí, veio eu. Eu ali no meio, eu ali no meio. Quando eu acordei, mesmo, eu já estava dentro do negócio.

Os caboclos demoraram a chegar na vida de Toinho, apesar de seu envolvimento na sessão de D. Nilza. A entidade que veio primeiro foi exu, o "escravo", e Toinho passou um tempo dando consulta com ele. Mas certa vez, quando um cliente veio em busca de exu, Mata Virgem passou na frente, como nos contou Toinho:

Ele veio e tomou o espaço. E hoje é ele quem manda e desmanda aqui dentro. É Mata Virgem. A palavra primeira e a última é dele. E depois disso eu trabalhava no mercado, vendia café na época. Ele mandou que eu viesse pra casa, descansar porque eu estava muito cansado. Isso tem 17 anos, eu estou descansando até hoje. Não voltei mais no mercado, ele quem mandou. Abaixo de Deus, é o vento que eu respiro. Então quando o Mata Virgem apareceu, eu trabalhava com o escravo, só fazia minha consulta. E quando o Mata Virgem apareceu, ele determinou que vinha pra trabalhar, ele queria candomblé, ele queria atabaque e ele queria a casa aberta.

Debates do NER, Porto Alegre, Ano 20, N. 38, P. I 45-I8O, AGo./DeZ. 2020 
Quando Mata Virgem chegou Toinho refez o caminho de Dona Nilza. Levou o caboclo para batizar com Dona Estela, mãe de santo do município de Terra Nova, não muito distante de Santo Amaro. O caboclo Rei do Congo, com quem Dona Estela trabalha, havia batizado Rei das Estrelas, caboclo de D. Nilza. Nada mais certo que batizasse também Mata Virgem. "Então a gente tem Rei das Estrelas como pai e Rei de Congo como avô".

À história das relaçóes de parentesco entre os caboclos, sobrepóe-se outra, de parentesco entre os humanos em cujos corpos Mata Virgem trabalhou e ainda a história da vida de Mata Virgem, índio Tupinambá:

Mata Virgem, ele conta que ele era de uma tia avó minha. Ele trabalhou. Essa tia avó tinha 35 anos de morta e ele voltou e retornou a terra para trabalhar. Ele conta a história que ele morreu, ele era um homem trabalhador, era um índio que morreu numa tribo Tupinambá. E ele voltou ao terreiro para trabalhar. É o caboclo da festa, é o caboclo que trabalha, é o caboclo do conselho. É o caboclo que quando chega uma pessoa no desespero, na aflição, atende as pessoas. É um caboclo querido pela comunidade, graças a Deus.

Mata Virgem ocupou o espaço do exu que baixava em Toinho. Quando chegou, mudou a rotina de Toinho: queria casa aberta, ciclo de festas e obrigaçóes. Selou o vínculo de Toinho com o mundo de sua mãe adotiva, e o conectou ao passado mais remoto de sua família. Mas impôs suas preferências: enquanto na casa de D. Nilza prevalecia a mesa branca, o terreiro de Toinho é de giro.

Os percursos dos caboclos deixam em seu rastro muitos tipos de conexão. Produzem laços de parentesco e amizade: caboclos são batizados por outros caboclos, cuidam dos seus parceiros humanos, ligam-se a outros humanos como curadores, conselheiros ou companheiros de copo, ligam humanos a seus territórios, ativam laços esquecidos e criam outros inesperados. Multiplicam e conectam diferentes planos temporais - os diferentes tempos dos

Debates do NeR, Porto Alegre, ano 20, N. 38, P. I45-I80, Ago./Dez. 2020 
humanos com quem trabalharam, o tempo de sua missão como caboclos e o tempo de suas vidas como índios, marujos, boiadeiros, aparecem, cada um, no horizonte do outro. Conectam lugares; quando chegam seus nomes já trazem paisagens móveis - Treme-Terra, Sultão das Matas, Mata Virgem, Rei das Estrelas, Gentileiro - que muitas vezes se encontram em um ritmo acelerado. E no seu movimento podem mesmo redesenhar o espaço do terreiro, abrindo nichos, passagens, zonas de encontro e convivência, como fez o caboclo de Roquinha ao demandar que a sessão de mesa branca fosse trazida para dentro do terreiro de candomblé, garantindo que no terreiro houvesse espaço também para quem não quer manter relações com o candomblé.

Os caboclos são mestres da composição.

\section{COMPOSIÇÓES}

No livro "Cidade das Mulheres", Ruth Landes relata seu encontro com Sabina, uma "mãe cabocla". Landes fora acompanhada por Edison Carneiro ao terreiro de Sabina, localizado no bairro da Barra. Quando Sabina teve oportunidade de explicar a Landes o seu candomblé, falou dos caboclos:

Esse templo é protegido por Jesus e Oxalá e pertence ao Bom Jesus da Lapa. É uma casa dos espíritos caboclos, os antigos índios brasileiros, e não vem dos africanos iorubá ou do Congo. Os antigos índios da mata mandam os espíritos deles nos guiar, e alguns espíritos de índios mortos há centenas de anos. Salvamos primeiro os deuses iorubá nas nossas festas porque não podemos deixá-los de lado; mas depois salvamos os caboclos porque foram os primeiros donos da terra em que vivemos. Foram os donos e, portanto, agora são os nossos guias, vagando no ar e na terra. Eles nos protegem (Landes, 2002, p. 232).

Debates do NER, Porto Alegre, ano 20, N. 38, P. I45-i 80, Ago./Dez. 2020 
Já é sabido que Sabina não era bem vista nos meios mais ortodoxos do candomblé de Salvador; Landes se refere ao desprezo que Mãe Menininha ${ }^{7}$ nutria não só por ela, mas pelo candomblé de caboclo em geral. Depoimentos colhidos por Donald Pierson, durante sua estadia na Bahia na década de 1930, mostram que esse desprezo era compartilhado entre os adeptos das casas jeje-nagôs, ciosos da sua herança africana. Falava-se então dos "imitadores" caboclos. Um dos interlocutores de Pierson, pai de santo de uma casa nagô assim se referiu a um conhecido pai de santo de terreiro caboclo:

Seus avós, que é que eles sabiam? Foram educados na seita? Será que deixaram o cargo para ele? Não! Ele veio do sertáo e quer fundar um candomblé. Aprendeu um pouco de gêge, um pouco de nagô, um pouco de congo, umpouco dessas coisas de índio e assim por diante. Que mistura desgraçada!" (Pierson, 1971, p.305).

"Se seja mistura, é bobage", disse-lhe outro.

A definição que Toinho nos oferece de seu terreiro pode ser tomada como um contraponto interessante aos comentários que Pierson colheu sobre o candomblé de caboclo:

Existe a linha da umbanda, existe o giro de caboclo, eu já sou giro de caboclo. Porque eu trabalho com caboclo, trabalho com candomblé e trabalho com a umbanda. Então se chama giro de caboclo porque vem uma coleção, uma mistura, um conjunto de várias mãos seguras.

Para Sabina, nas casas de caboclo é preciso louvar os orixás primeiro, por uma questão de cortesia, de educação: não se pode deixá-los de lado. Coleção e mistura são os termos usados por Toinho para descrever o giro de caboclo, modalidade de prática que define tanto seu terreiro quanto o de

${ }^{7}$ Mãe de santo de um dos terreiros mais antigos de Salvador, o Ilé Iyá Omi Asé Yamasé (mais conhecido como Gantois), onde Landes fez grande parte da pesquisa de campo que deu origem ao livro "Cidade das Mulheres".

Debates do NER, Porto Alegre, ano 20, N. 38, P. I45-I80, Ago./Dez. 2020 
Paulo. Se coleçáo ressalta a pluralidade que esses terreiros abrigam, mistura não pode significar indistinção. Seu sentido aqui remete mais à convivência (pessoas que se misturam) do que à produção (fruto de mistura): o modelo é social e não químico. Por que estariam os caboclos associados à mistura? Se lembrarmos que os caboclos são entidades em movimento, e que em casas como a de Toinho e Paulo estáo à frente das atividades do terreiro, entáo talvez possamos concluir disso que cabe também a eles parte importante do trabalho de composiçáo do terreiro como espaço em que novas conexóes podem se produzir.

No terreiro de Paulo, em meio às muitas árvores e plantas, uma bandeira branca erguida por uma haste comprida revela aos desavisados que ali se trabalha com forças invisíveis. Convida aos interessados em se beneficiar dessas forças a buscar a ajuda de quem sabe mobilizá-las. Passamos por ela, enquanto Paulo percorre conosco o espaço, mostrando plantas e lugares, contando a história do terreiro e de suas entidades.

- Aqui, venha ver aqui uma coisa. Você vai se apaixonar por esse cabra, venha ver ele aqui... Ó ele aí, ó o Boiadeiro aí! 
Fotografia 2 - Casa de Boiadeiro, terreiro de Paulo (foto de Antônia Oliveira, 2018)

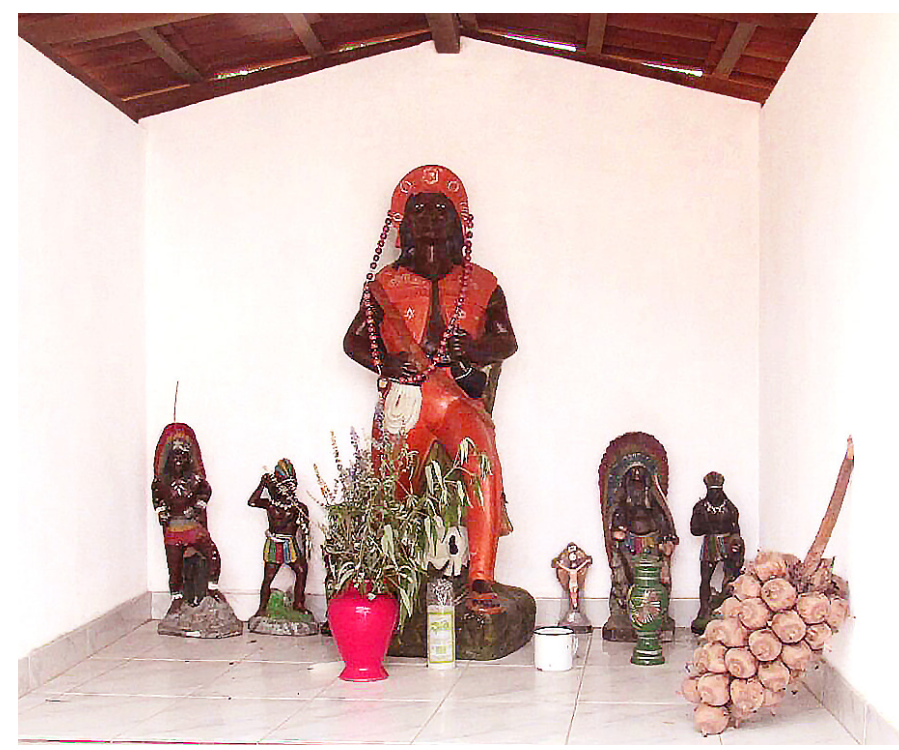

Uma casinha de telha sem a parede da frente abriga uma estátua de Boiadeiro, o corpo negro, calça, gibão e chapéu de couro. Ao seu lado imagens bem menores de caboclos de pena ${ }^{8}$ e outra menor ainda de Jesus Cristo. À frente uma quartinha vermelha com folhas de espada d'Ogum e uma vela de sete dias acesa. Ao lado um cacho de licuri.

- Meu caboclo é Gentio. Aí Boiadeiro já é outra entidade. Vêm vários, mas quem manda é Gentio. Ele é que domina tudo. Ele é que é o dono daqui, tá entendendo? O caboclo que manda aqui nessa casa... Vêm todos, mas a ordem é dele. $\mathrm{O}$ que ele diz que é isso, é isso.

- Você trabalha mais na linha de caboclo?

- Caboclo, caboclo.

8 Caboclos de pena são a classe de caboclos conhecidos como "índios", associados a elementos de origem ameríndia ou afroindígena. Alguns de seus nomes são: Sete Flechas, Sultão das Matas, Tomba Morro, Treme-Terra, Juremeiro, Pena Branca.

Debates do NER, Porto Alegre, ano 20, N. 38, P. I45-I80, Ago./Dez. 2020 
- Na linha de orixá também?

- Tudo. Aqui no orixá é Ogum. Eu sou de Ogum com Iemanjá, entendeu?

Paulo abre a porta de uma casa pequena, de um só cômodo, e explica que é ali que a comida das festas é dividida. Amontoados em um canto, vários inhames enramados. Ele nos explica que aquele é o inhame de Ogum, a ser oferecido para ele, com vistas a obter prosperidade e "coisas boas dentro de casa". Um pouco mais adiante, mostra-nos a gruta do caboclo. Segundo ele, a cada Dois de Julho9 oferece frutas e mel para Gentio - sem bebidas alcoólicas. Chegamos então à árvore de Boiadeiro, uma jaqueira. Paulo então explica:

- Esse pé de jaqueira é de Boiadeiro, de jaca dura. É o pé de Boiadeiro. No churrasco dele, na festa dele, ele não samba dentro de casa, samba do lado de fora. Boiadeiro manda cercar tudo de palha de dendê e o couro come aí. É carne, é cerveja. Que Boiadeiro gosta, né? De cervejada. A festa de Iemanjá eu fiz [na praia de] Cabuçu, eu dou presente de Iemanjá com Marujo. Recebo ele também, quando me pega eu levo dois dias doente.

Embora Paulo faça festas para Boiadeiro e para Marujo, a sessão semanal que acontece em seu terreiro é comandada por Gentio. "Aí ele é que vai dando ordem pros outros, pros médiuns. Cada médium, ele solta uma entidade, aí se torna um grupo ali de caboclo com ele junto. É uma força muito grande, é uma força muito grande". Na sessão os caboclos dançam no barracão, mas não bebem, só água e mel. Dona Maria instruiu Paulo a não os acostumar a beber.

- Porque já pensou? Tem dias que eu atendo das seis da manhã às seis da tarde. E [o caboclo] não sai não. Nem pra eu ir no banheiro, não sai não. E não sei, rapaz. Eles me pegam em festa aqui, dez da noite é a saída dele,

${ }^{9}$ Dois de julho é a data em que se comemora a independência da Bahia. Os caboclos (indígenas) são tidos como heróis da independência, não só celebrados nos festejos oficiais da data, como também nas casas de candomblé de Salvador e Recôncavo Baiano (muitas das quais fazem festa de caboclo no dia).

Debates do NER, Porto Alegre, ano 20, N. 38, P. I45-i 80, Ago./Dez. 2020 
dez da noite, e vai até seis da manhã. Couro comendo aí e sem largar pra nada. Mas porque vem com as forças deles mesmo. Agora meu Boiadeiro bebe, meu Marujo bebe, meu Marujo fuma. Já é outras coisas. Mas o da mesa mesmo, o dono da mesa...

Uma vez por ano, Paulo também dá comida para os exus, mas sem toque, porque a linha da sua casa náo permite. No terreiro de Paulo tudo é feito na linha branca:

-Na linha do dendê eu não mexo, entendeu? Nada não vai azeite (de dendê) aqui. Nada, nada. Obrigaçáo de santo nenhum. Minha linha não permite dendê não, não aceita dendê não. E nem cortar. Raspar sim, mas cortar ${ }^{10}$ não. (...) Ela (dona Maria) também não mexia não. (...) Nós [também] não mexemos em nada de morto. Cemitério nós não vamos. (...) Mata eu adoro, adoro mata, adoro água. Qualquer mata se me chamar eu entro, não tenho medo. Mas cemitério, eu tenho pavor de quem morre. E aí é a vida.

A casa de Paulo, como a de dona Maria, é de linha branca - não se corta para as entidades, não se toca para exu, oferendas só com mel e azeite doce. Também é lugar de confluência de muitas linhas: de caboclo, orixá, exu, preto-velho. E é espaço recortado, definido mesmo, pelas relaçóes entre os caboclos, tendo à frente Gentio, o dono de tudo, segundo o próprio Paulo. Em cada uma dessas formulaçóes, temos um modo próprio de desenhar o espaço do terreiro e distribuir suas diferenças. Em duas delas linha é palavra-chave - na primeira, define a tradição da casa, o modo de atuar que Paulo aprendeu com sua mãe de santo e que ele buscou imprimir na conduta dos seus caboclos; na segunda o modo de lidar com cada tipo de entidade (orixás, exus, caboclos, etc.) que em geral define a casa como candomblé, mesa branca, umbanda ou giro. Mas ao ser definido pelos caboclos, o espaço do terreiro ganha novos contornos: as diferenças entre linhas como tradiçóes ou entre linhas como modos de trabalhar para diferentes tipos

10 "Cortar" é uma forma de se referir ao abate cerimonial nas religióes de matriz africana.

Debates do NeR, Porto Alegre, ano 20, N. 38, P. I45-I 80, Ago./Dez. 2020 
de entidades (que se traduzem em diferenças entre candomblé e umbanda ou giro e mesa branca, por exemplo) se convertem em diferenças entre os temperamentos dos caboclos da casa. Cada caboclo projeta uma zona própria de afeto e influência capaz de atrair outros caboclos e humanos, fazendo-os gravitar em seu entorno. As linhas, neste caso, orientam-se e convergem para o foco (temporário) de atração. Gentio comanda a sessão, chama e junta os caboclos da casa para trabalhar, mas só com água e mel, conforme foi acostumado. Qualquer caboclo pode chegar, mas a ordem é sua - nada de bebida. Quando a festa é de Boiadeiro, a cerveja corre solta para humanos e caboclos. E quando se trata de festejar Marujo, marinheiro beberrão, sua afinidade com o mar, permite que sua festa seja feita junto com Iemanjá, divindade iorubana das águas salgadas.

Não muito distante do terreiro de Toinho, está o Centro de Caboclo Jaguaraci de Mãe Zenaide. Fomos procurá-la por indicação de Toinho que, orgulhoso, disse tratar-se de uma filha de santo bem mais velha do que ele e que já tinha casa aberta. A casa tem uma varanda fechada na frente que dá entrada a uma sala de estar; ao final de um corredor, chega-se ao barracáo. Dona Zenaide náo se encontra e é Nayran, sua filha (biológica) quem nos recebe.

Toda terça feira, mainha dá sessão aqui, onde tem os clientes, amigos, irmãos de santo que vêm, aí tem a sessão, oraçóes, pede pelas vidas das pessoas que estão em hospitais, doentes em cima da cama, proteção às pessoas, aí depois de tudo o caboclo responde, o caboclo decide, os que estáo sentados na mesa também respondem, aí depois tem um passe, como se fosse uma limpeza de corpo, que faz é o guguru, que no caso é a pipoca, que passa nas pessoas, e aí depois tem o encerramento com muita cantiga, alguma coisa pro pessoal que veio comer e aí o pessoal vai embora, tod a terça feira de 15 em 15 é realizada a sessão. 
D. Zenaide tem dois caboclos, Gentileiro e Jaguaraci, ambos caboclos de pena, embora Gentileiro tenha mais de uma forma: "o caboclo de Mainha é o caboclo que na verdade o povo diz que ele é um caboclo de couro... tem gente que conhece ele como um caboclo índio e tem gente que conhece ele como um caboclo de couro, porque ele pode vir trajado das duas coisas, tanto do couro como da pena". Gentileiro é o caboclo da sessão; Jaguaraci "é mais pro candomblé". Ele foi responsável por uma famosa adição à casa de dona Zenaide: uma jiboia, guardada em um armário transformado em viveiro, no corredor que dá para o barracão. Uma foto pregada na parede do barracáo exibe a jiboia enrolada no pescoço de Jaguaraci, pela porta de vidro do armário a vemos enroscada em um pedaço de pau. Nayran conta que Jaguaraci vivia pedindo que lhe trouxessem uma cobra e que até o dia em que ganhou a jiboia de uma máe de santo que lhe tinha muito apreço, a casa de dona Zenaide era constantemente visitada por cobras. 
Fotografia 3- Foto do caboclo Jaguaraci na parede do barracão de dona Zenaide (foto de Antônia Oliveira, 2018)

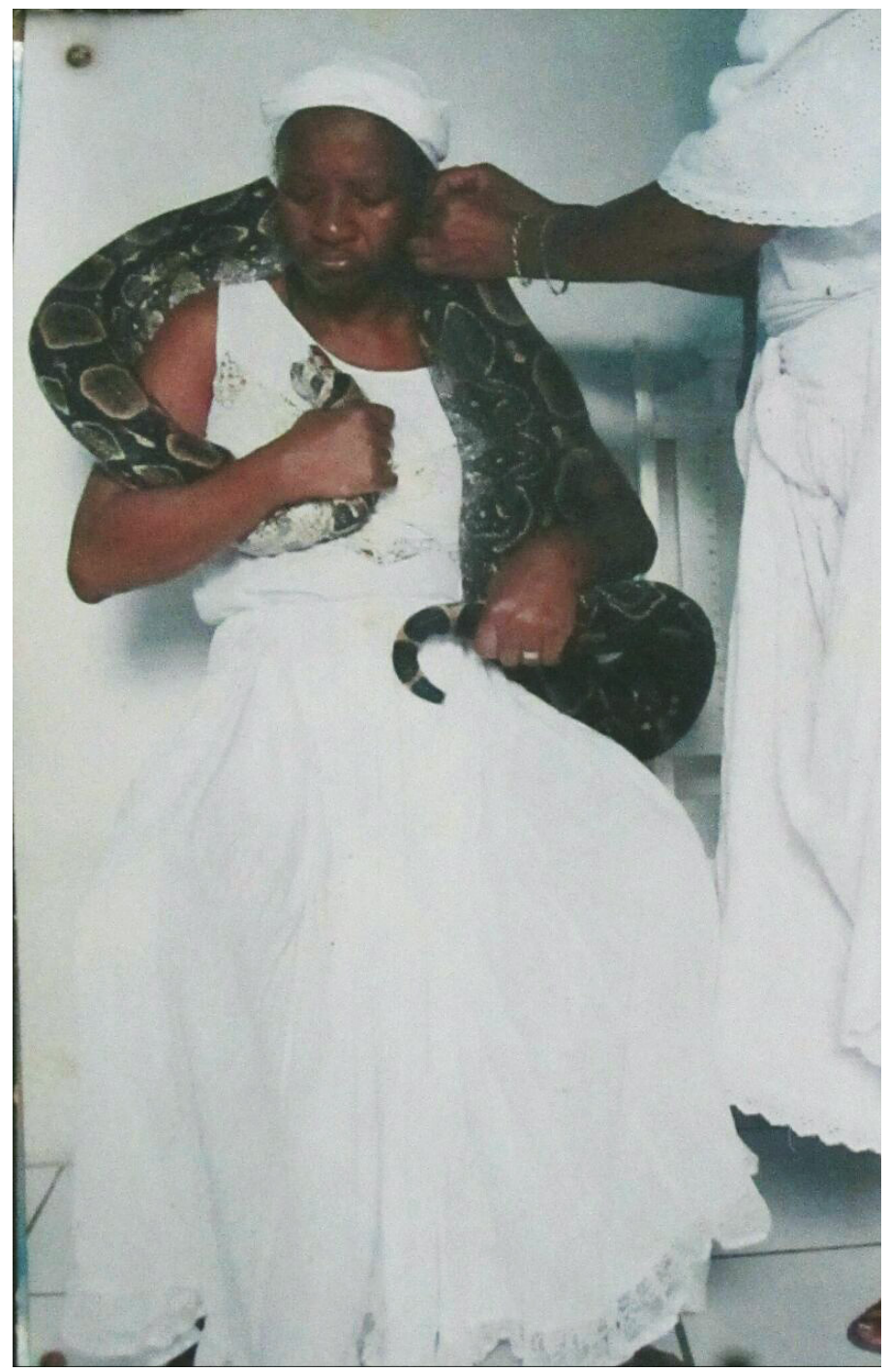

Como Jaguaraci, o caboclo de Nayran - Juremeiro - não tem afinidade com a sessão - "é só de festa". "Às vezes até me apanha na sessão, mas não 
fica não, por causa do respeito". Interessante notar que é o respeito que mantém o caboclo da gira distante da sessão: a questâo central aqui é menos a preservação de uma tradição contra misturas, do que a consideração pelo espaço do outro - a vinda de um caboclo festeiro na sessão ameaça a boa convivência, no terreiro, entre caboclos de sessão e de giro.

Nayran é de candomblé. No decorrer da conversa nos damos conta que também ela é mãe de santo, embora não fique claro se já tem filhos iniciados. Emoldurados na parede do barracáo estáo seu registro de sacerdotisa de culto afro e o alvará de seu terreiro de candomblé ketu, o Ilê Ase Oju Oba Layó, ambos expedidos pela Fenacab. Também na parede do barracão vê-se a moção de reconhecimento concedida à d. Zenaide pelo Bembé do Mercado de Santo Amaro ${ }^{11}$. Entre Nayran e dona Zenaide estabeleceu-se uma espécie de acordo de cooperação, ou de "divisão de trabalhos": "Ela cuida das coisas dela e... tem filhos de santo dela... que ela cuida também... uma comida, faz as coisas tudo direitinho. Aí quando aparece alguém que seja pra poder raspar, ela já passa pra mim".

Nayran explica que no barracão são celebradas as festas de seu orixá, Xangô, e do caboclo Juremeiro - "agora sempre separadamente, quando é festa de Ogum (orixá de D. Zenaide) é de Ogum, quando é festa de Xangô... agora geralmente quando é a festa do caboclo, aí a gente faz junto".

O fato de serem mãe e filha certamente contribuiu para que esse arranjo tomasse forma. Mas também contribuíram as inclinaçôes de seus caboclos.

As diferenças entre caboclos (e entre eles e os orixás) distribuem-se náo só no espaço dos terreiros, como também no tempo - no calendário

${ }^{11} \mathrm{O}$ Bembé do Mercado é uma celebração religiosa afro-brasileira realizada na cidade de Santo Amaro, no Recôncavo Baiano. Teve início em 1889, em comemoração à abolição da escravatura, e fruto do empenho das comunidades de terreiro de Santo Amaro. Comporta hoje três dias de festa de rua em honra aos orixás.

Debates do NER, Porto Alegre, ano 20, N. 38, P. I45-I 8o, Ago./Dez. 2020 
de suas festas. Assim como vimos nos arranjos espaciais das casas de Paulo e Nayran, aproximaçôes e distanciamentos no tempo são orientados tanto pelas inclinaçóes dos distintos caboclos, quanto por uma preocupação com a boa convivência entre eles.

$\mathrm{Na}$ casa de Toinho, toda quarta feira tem sessão de caboclo. Durante a quaresma, essa se resume à mesa branca, mas no resto do ano é sessão de giro. Toca-se também para os orixás no giro de caboclo, ele explica, mas quando é festa de orixá, tudo é feito no ketu.

No calendário da casa, além das sessôes, tem-se uma sequência de festas: Ogum, orixá de frente de Toinho, em janeiro; Mata Virgem, em julho; Obaluaê, em agosto; caruru de Cosme e Damião em setembro e o presente das águas em dezembro. As duas primeiras são as festas mais importantes, vários dias de preparativos e vários dias de celebração. Perguntamos se os caboclos vêm na festa de Ogum.

Sempre quando depois que a gente faz o xirê, depois que Ogum toma rum ${ }^{12}$, a gente serve a feijoada para a comunidade, tem aquela uma hora de descanso e depois a gente vira pra caboclo. $\mathrm{O}$ caboclo aqui em casa não fica fora de nada, de nenhuma situação, nem eles mesmos não se permitem. Ontem eu tentei até dar uma escapulidinha, [mas] ele vem.

E hoje estou lutando para que eu deixe também um legado, porque casa de caboclo aqui em Santo Amaro tá bem pouco...

\section{CASA DE CABOCLO}

Abaixo temos três excertos, de diferentes fontes, que tratam do caboclo e seu culto em religióes de matriz africana:

12 No candomblé, tomar rum é dançar ao som dos tambores, ou ser provocado pelos tambores a dançar.

Debates do NER, Porto Alegre, ano 20, N. 38, P. I45-i 80, Ago./Dez. 2020 
Já em São Luís fala-se mais de uma 'quase invasão' de entidades espirituais caboclas nos terreiros de Mina. Adianta-se que, uma vez acolhidas pelos pais de santo, estas entidades ensinaram novos cânticos e danças e aqueles passaram a realizar para elas ritos especiais impregnados de elementos culturais indígenas ("dança batendo os pés ou imitando guerra, uso de arco e flecha, maracá e de adornos de penas", etc.) (M. Ferreti, 1994, p.23).

Têm-se falado aqui, às vezes muitos oradores disseram, que o candomblé, chamado assim ou assado, foi de um mais velho do que outro. Mas o caboclo é mais velho, porque os outros vieram de lá pra cá, e ele já estava aqui. Ninguém foi buscar "ele" não. Ele já estava aqui. Ele é o dono da terra. E por que, agora, se expurga o dono de suas casas? Se acha que caboclo não tem prestígio, se acha que caboclo não é "feito", se acha que ele não tem pai, nem mãe, que nasceu num oco-de-pau? Caboclo não nasceu assim, não. Ele tem pai, mãe, tem tudo. Caboclo é uma "nação", tem bandeira, tanto quanto outra qualquer, mas não é bandeira de Tempo como botam. Ele tem bandeira, porque a bandeira dele é a Nacional. É a Bandeira Brasileira, verde, amarela, "Ordem e Progresso". O Brasil não é uma nação? O caboclo não é brasileiro? (Ferreira, 1984, p. 65).

Eu acho que a porta do candomblé é o caboclo, caboclo que traz, caboclo que leva. Exu é o mensageiro, mas quem traz é o caboclo. É caboclo que tem a liberdade, é caboclo que tem a ousadia, é o caboclo que entra no mato na hora que ele quer, sai a hora que ele quer, então eu acho que o candomblé tem muito a ver e a dever aos caboclos sim. Caboclo é a entrada e saída de tudo... (Pai-de-santo de Salvador em entrevista a Ana Sheldon, 2019).

O primeiro trecho apresentado é parte da narrativa que pais e mães de santo ofereceram a Mundicarmo Ferreti sobre a entrada do culto aos caboclos no tradicional Tambor de Mina: "uma quase invasão". O segundo foi extraído de palestra sobre o candomblé de caboclo proferida por Almiro Miguel Ferreira, em 1983, durante o Encontro de Naçôes de Candomblé, 
realizado em Salvador. Enquanto os informantes de Ferreti apontavam para a entrada dos caboclos nas práticas religiosas africanas do Tambor de Mina, Ferreira enfatizava a anterioridade dos caboclos - não precisou ninguém os buscar, estavam já aqui muito antes dos orixás terem sido trazidos. Até por volta de 1944, conta Ferreira, o candomblé de caboclo tinha presença forte em Salvador; com o prestígio crescente do candomblé africano, sacerdotes do culto aos caboclos teriam migrado e refeito seus cultos nos moldes do candomblé keto, jeje ou angola. Como resultado, por volta de 1944 o candomblé de caboclo teria se extinguido na Bahia (Ferreira, 1984), vencido pelo modelo do culto aos orixás.

Apesar das diferenças - o discurso da anterioridade contrasta claramente com o discurso da intrusão (às vezes formulado como uma história de mistura ou corrupção) - esses dois trechos levantam questóes que durante certo tempo ${ }^{13}$ ocuparam a atenção de pesquisadores das religióes de matriz

${ }^{13}$ As referências a uma modalidade de candomblé, conhecida como candomblé de caboclo, são bastante antigas e praticamente todas giram em torno da determinação de sua origem. Em 1906 Nina Rodrigues (2010) a descreveu como resultante de um processo de adiçáo de fragmentos de crenças ameríndias ao que era essencialmente o candomblé africano, tal como praticado entre os povos de origem banto (cuja pobreza ritual, segundo ele, os fazia mais abertos a incorporaçôes estrangeiras). Poucos anos depois, em 1919, Manuel Querino (1938) propôs tratar-se de uma modalidade de culto surgida da convivência íntima entre indígenas (catequizados) e africanos. Mas foi a posição de Rodrigues que dominou o debate na primeira metade do século XX. Tanto Arthur Ramos (1940) quanto Edison Carneiro (1948) viram o candomblé de caboclo como essencialmente um candomblé banto a que foram acrescentados elementos do espiritismo e da mítica ameríndia (apesar de concordar com Ramos nesse ponto, Carneiro náo falhou em observar que os encantados caboclos também se faziam presentes em casas nagôs). A associação direta entre candomblé banto/angola e culto aos caboclos (presente, nas análises de Rodrigues, Ramos e Carneiro), levou Santos (1995) a questionar se a categoria candomblé de caboclo de fato demarcaria um campo empírico próprio. Para este autor, ao invés de circunscrever uma modalidade distinta de candomblé, o termo serviria para indicar os terreiros em que o culto aos caboclos tinha proeminência (muitos dos quais se definiam como naçấo caboclo). No mundo dos candomblés baianos, seu emprego

Debates do NER, Porto Alegre, ano 20, N. 38, P. I45-I80, Ago./Dez. 2020 
africana. Como e quando os caboclos ganharam espaço nessas religióes? Teria realmente existido um culto dedicado exclusivamente aos caboclos que se extinguiu nos anos 1940, conforme frisa Ferreira (1984), ou seria o candomblé de caboclo apenas um nome dado aos candomblés que primeiro, e de modo mais conspícuo, abriram suas portas aos caboclos, sacrificando assim a tradição africana (quase uma categoria de acusação, conforme aponta Santos, 1995)?

É possível dizer que essas questões, embora difíceis de responder (até porque tratam de uma história marcada por muitas especificidades e variaçôes regionais), valem a pena serem perseguidas - afinal podem esclarecer aspectos importantes relativos à formação do campo religioso afroindígena na Bahia e país. Mas o modelo cronológico linear pressuposto na sua formulação - a ideia de que podemos traçar uma linha de desenvolvimento/transformação a partir de um ponto localizado de origem - pode ter como efeito tornar invisíveis os muitos e complexos trajetos através dos quais caboclos se cruzam, entram nas vidas das pessoas (humanas) e vêm a conviver com orixás (vimos alguns desses caminhos nas histórias de Toinho, Paulo e Nayran).

Os relatos de Ferreti e Ferreira também têm algo a dizer sobre esse último ponto. Os caboclos chegaram na Mina sem ser convidados, negociaram entrada, ensinaram seus modos e cantigas (e provavelmente também aprenderam). Conforme Ferreira, em Salvador, perderam com o tempo seu culto próprio, mas adaptaram-se às regras das casas de candomblé de tradição africana. Passaram, nos dois casos, a dividir espaço com voduns, orixás ou inquices. Ambas narrativas testemunham a persistência dos caboclos. E enfatizam seu movimento: o percurso de quem chega, se acomoda ou reacomoda segundo as possibilidades da situação.

O depoimento do pai de santo de Salvador traz um elemento novo: não só fala da presença dos caboclos em cultos de matriz africana como permite

teria uma finalidade política: servia como categoria usada pelas casas que se definiam pela fidelidade à tradição africana, para marcar sua distinção com respeito a terreiros vistos como sincréticos ou misturados.

Debates do NER, Porto Alegre, ano 20, N. 38, P. I45-I80, Ago./Dez. 2020 
articular uma perspectiva bem diferente para abordar a relação entre essas entidades e os orixás. Aqui já não se trata nem de afirmar a anterioridade dos caboclos, nem de relatar sua entrada nos cultos de origem africana: a pertença dos caboclos ao candomblé é tomada como fato. O importante é definir seu lugar, ou melhor, sua função - definir os caboclos pelo que eles fazem: levar e trazer. Interessante a diferença sutil entre caboclo e Exu: este é o mensageiro, mas quem leva e traz (transporta) é o caboclo. Talvez essa diferença possa ser traduzida em outros termos ainda: se Exu domina a arte da tradução que permite a comunicação entre humanos e deuses, o caboclo domina a arte do transporte - porque é "da terra", conhece bem seus territórios e tem a ousadia necessária para percorrê-los livremente.

As cantigas de caboclo ilustram bem esse ponto: nelas os caboclos chegam trazendo para dentro do terreiro territórios de mata, sertão e água. No jarê, candomblé de caboclo da Chapada Diamantina, região central do estado da Bahia, é assim também que chegam os orixás: como caboclos. Enquanto nos terreiros do Recôncavo que se identificam como giro de caboclo ou umbanda, os orixás são cultuados com os caboclos (segundo diferentes formas de distanciamento e aproximação), no jarê, são cultuados como caboclos ou simplesmente são caboclos (Senna, 1984; Rabelo, 1990, 1993; Bannagia, 2015), em um processo que Senna (1984) definiu como “caboclarização".

Para encerrar nosso percurso pelo mundo dos caboclos, vamos ao terreiro de seu Agenor, curador de jarê que uma de nós (Miriam) conheceu em 1987.

Agenor tinha um pequeno lote no Corujão, comunidade rural localizada no município de Nova Redenção, área de agricultura camponesa na Chapada Diamantina. Vivia, como a maioria dos seus vizinhos, do cultivo da terra, mas também do seu trabalho como curador de jarê. Antes de trabalhar no couro (como o jarê era também conhecido, em referência aos tambores que batiam nas festas para louvar os caboclos), foi curador de sessão (seus caboclos ou guias chegavam para rezar e dar assistência aos 
clientes que o procuravam). Quando depois de uma vida de andanças - ao sabor da disponibilidade de terra para plantar - se estabeleceu no Corujão, aproximou-se do jarê. Teve como mestre no jarê um famoso curador do município vizinho de Ibiquera. Nas festas de jarê, que passaram a ocorrer todo sábado em seu modesto terreiro, começava sempre com um circuito de rezas em latim que, uma vez findado, dava lugar à dança dos caboclos. Estes "vadiavam" ao som dos tambores até altas horas da noite, quando Agenor suspendia a brincadeira das entidades para dar início às atividades de cura. Trabalhava com seu caboclo Antônio Silvino, um Preto-Velho, também referido como Baluaê.

Fotografia 4 - Caboclo Antônio Silvino, jarê de Agenor (foto de Miriam Rabelo, 1987)

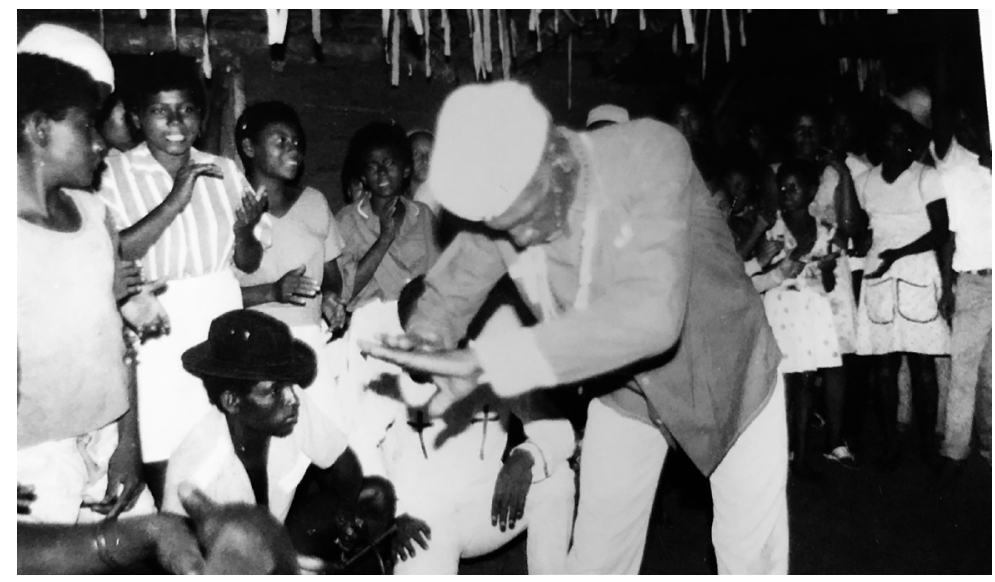

Era também Antônio Silvino quem abria a festa dos caboclos, chegando com o corpo curvado pelo peso dos anos. O caboclo falava com uma voz cansada, mas suas palavras tinham o tom de desafio. "Eu náo tenho papa na língua", costumava dizer. Os cantos entoados por Antônio Silvino e pelos outros caboclos que chegavam no terreiro descreviam os territórios de onde vinham e por onde passavam, desenhando um quadro do movimento 
a que se refere o pai de santo entrevistado por Sheldon. Seguem algumas cenas retiradas do relato de uma festa realizada na casa de Agenor em 1987.

Depois de uma baforada no charuto, Antônio Silvino clamou: "Viva Cristo Rei! Viva Nossa Senhora! Viva Rei Ogum! Viva Tomba Morro! Viva Tranca Rua! Viva o velho Antônio Silvino!” A cada salva, os presentes respondiam: "Viva!" Dona Rosa, mulher de Agenor, entregou um cajado ao caboclo do marido. Antônio Silvino puxou uma cantiga, dançando com o corpo apoiado no cajado:

Ói o véio, ói o véio

que lá vem beirando o mar

Ói o véio, de tấo véio

já num guenta mais andar

Baluaê, nego véio

O meio do mundo é aqui

vem visitar meu peji

O povo fez coro animado: "O meio do mundo é aqui". O caboclo entregou o cajado e cantou, remando com os braços erguidos:

Canoeiro bate o remo

pra canoa não virar

Canoeiro bate o remo

que eu quero atravessar

À certa altura, parou e fez um sinal da cruz. O gesto sinalizou a chegada de outro caboclo. Era o Ogum:

Ogum, Ogum é curador

Ogum é dos primeiros

que nesta casa chegou

Depois de entoar alguns cantos e distribuir bênçãos aos presentes, Ogum se retirou do corpo de Agenor. Em retribuição à cachaça que o curador

Debates do NER, Porto Alegre, ano 20, N. 38, P. I45-I80, Ago./Dez. 2020 
mandou servir aos tocadores, um deles puxou outra cantiga pra Ogum. O ritmo dos tambores se intensificou. Vãa, ajudante de Agenor, e duas mulheres da vizinhança foram tomados por Ogum. O Ogum de Vã foi o primeiro a puxar cantiga em meio a passadas largas e seguras, mas logo se foi deixando o rapaz visivelmente abalado num canto do barracão. Com Ogum, as mulheres seguiram dançando fazendo girar com velocidade as longas saias floridas.

Boa noite rei

rei de tremer terra

Chegou rei Ogum

que tava vencendo guerra

Areia, areiá

vamos jogar areia no mar

Eu não vim escondido

Eu vim vadiar

A dança dos caboclos seguiu ainda por muito tempo. "Isso aí, caboclo!" gritaram os tocadores, contentes com o samba. Também satisfeito, o curador cantou:

A casa pode, papai

O terreiro aguenta seus filhos

Comprovando a abertura e força da casa para suportar a presença de seus filhos, o jarê de Agenor viu ainda chegarem para "vadiar" as Titias Nagôs e Iansã, Sultão das Matas, Sete Serras, Gentio, Tomba Morro, Oxóssi, Xangô e Gentileiro. 
Fotografia 5 - Caboclo Sultão, jarê de Agenor, 1987 (foto de Miriam Rabelo, 1987)

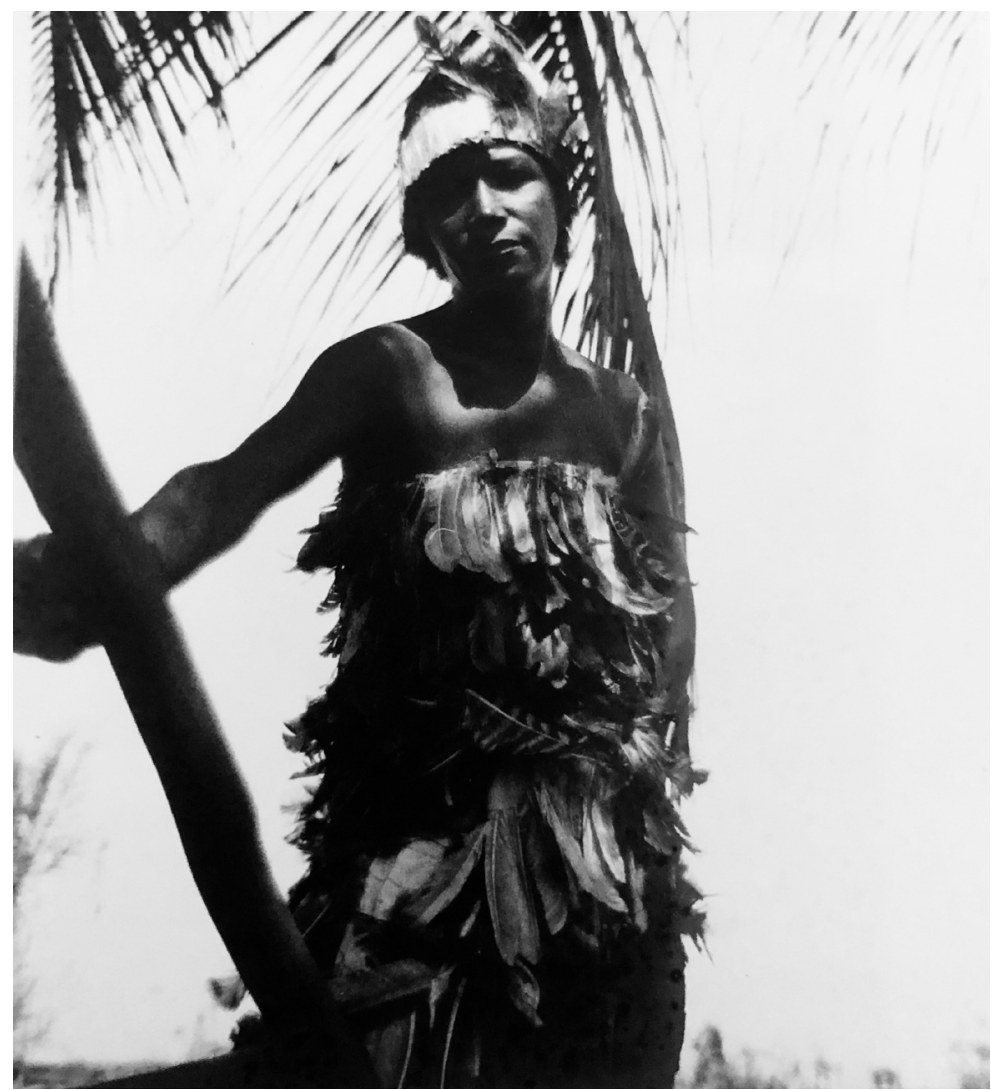

\section{ESPAÇOS E ENCONTROS}

Em uma conferência de 1973, intitulada "O encontro entre deuses africanos e espíritos indígenas” (publicada em português em 2006), Bastide propóe uma tipologia das religióes afro-brasileiras a partir das relaçôes, aí encontradas, entre orixás e espíritos ameríndios. $\mathrm{O}$ primeiro tipo corresponde

Debates do NER, Porto Alegre, ano 20, N. 38, P. I 45-I 80, Ago./DEZ. 2020 
à separação nítida entre duas modalidades religiosas que coexistem sem se interpenetrar - o catimbó e o candomblé ou, mais especificamente, o candomblé iorubá que não aceita a entrada dos caboclos. No segundo tipo, exemplificado pelos candomblés bantos (ou de nação angola), observa-se a incorporação do culto dos caboclos ao espaço do terreiro. Essa incorporação, entretanto, se dá de um modo que preserva a autonomia entre caboclo e orixá - cultuados em festas separadas e segundo princípios diferentes. O terceiro tipo corresponde à macumba carioca. Orixás e caboclos são aí honrados em uma mesma cerimônia, mas segundo uma ordem (os deuses africanos primeiro, os caboclos quando estes já se foram) que evita a mistura. Comparada aos candomblés bantos, explica Bastide, a macumba teria produzido uma contração do tempo que mantém separadas as duas entidades. Assim, conclui o autor, apesar das diferenças, candomblé iorubá, candomblé banto e macumba são reveladores de uma mentalidade - africana - que rejeita a confusão dos gêneros, substituindo a mistura ou interpenetração por diversas formas de "compartimentação das entidades espirituais" (Ibid, 2006, p. 224).

Finalmente, observa Bastide, no espiritismo de umbanda teríamos uma efetiva integração entre os dois cultos. Os orixás deixam de incorporar em uma religiáo centrada no culto aos espíritos desencarnados (entre os quais se incluem os caboclos), mas são alçados à condição de chefes das falanges em que se distribuem esses espíritos. Pode-se notar que, mesmo aqui, divindades africanas e caboclos seguem separados, ainda que por uma fronteira bem mais tênue.

A chave da tipologia é uma noção de distância espacial (medida pelo grau de aproximação ou separação entre os locais de culto aos orixás e aos caboclos) e temporal (medida pela aproximação/separação entre os períodos rituais dedicados a uma ou outra dessas entidades). Em "Os Problemas do Sincretismo Religioso" (volume 2 de "As Religiōes Africanas do Brasil", 1985), Bastide já havia desenvolvido tipologia semelhante para tratar do sincretismo entre o catolicismo e a religiosidade de matriz africana. Embora aí o foco de sua análise não seja o encontro entre deuses africanos e espíritos 
indígenas, vale a pena nos determos na classificação que emprega, pois esclarece aspectos do texto de 1973.

Bastide propõe tratar do sincretismo a partir de três planos de análise: o plano ecológico, o plano dos ritos e estruturas cerimoniais e o plano das representaçóes coletivas. Aos dois primeiros correspondem, grosso modo, os vetores de análise que utiliza ao discutir o sincretismo afro-indígena e por isso trataremos especificamente deles aqui.

$\mathrm{O}$ arranjo de objetos em que se inscreve a presença de orixás e santos católicos e sua distribuição pelo terreiro (formando zonas ou regiôes) constitui fonte para o entendimento do sincretismo naquilo que o autor denomina de sua dimensão ecológica. Uma vez que o espaço ecológico é regido pela justaposição - objetos materiais podem apenas estar ao lado ou próximos uns dos outros, mas nunca se fundir - "graus de sincretismo aqui se manifestarão pelo maior ou menor grau de aproximação ou afastamento entre o que se poderia chamar de regióes católicas e de regióes africanas num mesmo espaço sagrado" (Bastide, 1985, p.376). Assim tem-se uma variação que vai da existência de dois altares em um mesmo terreiro, situados em lugares diferentes - o altar católico no saláo de danças, o africano no peji - à adição de decoraçóes católicas nos altares africanos ou de quadros de santos católicos nas paredes do peji - "os dois espaços teoricamente separados, tendem, pois a se interpenetrar" (Ibid, p. 377) -, até a abolição mesma do peji (zona africana) e a coexistência em um mesmo altar de elementos materiais católicos e africanos.

O segundo plano tem o tempo como uma de suas dimensóes e traz a questão de como se relacionam ritos católicos e africanos no calendário de festas dos terreiros ou no transcurso de uma mesma celebração. Conforme Bastide, o plano temporal "nos póe em presença dos mesmos problemas e das mesmas soluçóes que o plano espacial” (p. 378). Também aqui são identificados tipos que variam conforme o grau de separação ou interpenetração entre as sequências rituais.

É possível usar a tipologia de Bastide para caracterizar as casas que descrevemos. Em linhas gerais parecem se aproximar do "tipo" macumba ou 
se situar entre o candomblé angola e a macumba - manifestações religiosas em que os caboclos ocupam compartimentos próximos, mas separados, daqueles reservados aos deuses africanos e suas formas de culto.

Várias configuraçôes aqui descritas parecem se conformar a esse tipo. Caminhando pela área externa do terreiro de Paulo, encontramos lugares bem demarcados - grutas, árvores, pedras, pequenas construções - lugares de caboclo e lugares de orixá. $\mathrm{Na}$ área interna, o altar católico situado em um canto do barracão e o peji em um quarto separado marcam uma zona católica e uma zona africana e sugerem sequências rituais bem diferentes. No terreiro de Toinho, o calendário de celebrações mantém a separação entre festa de orixá (realizada no keto) e festa de caboclo (embora, os caboclos "não fiquem fora de nada) e no espaço compartilhado de dona Zenaide e Nayran, sessão de caboclo e candomblé não se confundem. Em todos esses lugares, a "mistura” parece ser evitada pela existência de compartimentos (tanto espaciais quanto temporais).

Mas se a ideia de um espaço/tempo mensurável por distâncias mais ou menos fixas e passível de divisão em compartimentos parece acenar com um caminho para classificação e comparação entre terreiros de acordo com o modo como caboclos e orixás são aí postos em relação (e para uma teoria do sincretismo afro-indígena-católico, como pretendia Bastide), a intensa movimentação dos caboclos que registramos aqui sugere que esse modelo só funciona às custas de uma simplificação excessiva.

Uma das fraquezas do modelo de Bastide é que nele tanto o espaço, quanto o tempo são reduzidos à extensão. Enquanto o espaço é a extensão em que estão distribuídos objetos, o tempo é a extensão em que se distribuem sequências que podem estar mais ou menos separadas e que nos tipos mais sincréticos tendem a se interpenetrar ou mesmo se fundir. Nesse modelo, o movimento só pode ser descrito como deslocamento de um ponto a outro ou de um compartimento a outro em uma série tempo-espacial.

O quadro muda completamente quando espaço e tempo são pensados a partir do movimento - ou a partir de uma abordagem que ressalta sua produção prática. Se antes a única questáo que o movimento dos caboclos 
permitia articular dizia respeito à preservação ou não de uma distância com relação aos orixás, agora a atenção se volta para as diferentes formas espaciais que o movimento dessas entidades contribui para produzir e às possibilidades de convivência implicadas em cada uma delas.

Ao seguirmos o movimento dos caboclos a partir dessa mudança de foco, nos deparamos com uma topologia móvel. Na casa de Paulo, os caboclos Gentio e Boiadeiro recortam, com seus diferentes temperamentos, as outras divisôes do terreiro, criando centros de força que puxam entidades, objetos e lugares ora em uma, ora em outra direção. No espaço compartilhado de dona Zenaide e Nayran, afinidades entre Jaguaraci e Juremeiro instauram uma zona de interseção entre o candomblé de uma e a umbanda da outra: na casa de Zenaide, caboclos mais chegados ao candomblé tendem a se manter afastados da mesa branca ("por questão de respeito"), mas podem bem se juntar aos caboclos do candomblé de Nayran. E na casa de Toinho, a ubiquidade dos caboclos - que não podem ficar de fora de nada - sugere que "virar (a festa) pra caboclo" é menos operar um deslocamento temporal (de um compartimento de tempo a outro), do que fazer girar o espaço para deixar ver o que estava temporariamente oculto (mas presente) - ou talvez trazer para frente o que, na festa dos orixás, funcionava como pano de fundo. A depender de como são "provocados" ou "ativados" por afetos e afinidades que funcionam como verdadeiras forças de atração, espaços (e objetos) podem assumir formas diferentes.

Esses processos de espacialização falam de uma ecologia - ponto que Bastide não falhou em perceber. Mas a questão ecológica interessante que levantam não diz respeito às relações de justaposição entre objetos rígidos, senão às possibilidades de convivência entre seres - caboclos, orixás e os humanos que veem seus corpos transformados pela companhia dessas entidades.

É justamente no sentido de convivência que Toinho emprega a palavra mistura: em referência às possibilidades de compor um coletivo a partir de uma coleção e à força que advém de "um conjunto de várias mãos seguras". Essa ideia está presente também na festa de Agenor, quando o terreiro é 
performado justamente como o espaço - "o centro do mundo" - capaz de atrair e aguentar a movimentação intensa de entidades e territórios - o mar, o mato, o sertáo.

No esquema de Bastide, o jarê corresponderia justamente à mistura como interpenetração e confusão de gêneros, degradação da memória africana sob efeito da pobreza e dispersão a que foram expostas as populaçóes de afrodescendentes nas zonas rurais. Mas se pensamos a ecologia nos termos de Toinho, talvez possamos dizer que enquanto na umbanda e na gira, caboclos e orixás experimentam aproximaçóes e convivem em arranjos que sáo produzidos, em grande medida, sob efeito da movimentaçáo dos primeiros, no jarê é justamente porque vêm como caboclos, portando territórios de água, mata e sertáo, que os orixás podem conviver no terreiro. Ou ainda: no jarê, caboclo é justamente a maneira de existir junto de caboclos e orixás.

\section{O QUE DIZER, ENTÃO, DOS CABOCLOS?}

Neste texto seguimos alguns rastros deixados pelos percursos dos caboclos nos terreiros e nos corpos de pais e mães de santo baianos que mantêm com eles estreita relação. Entidades que escapam a definiçôes precisas, os caboclos se destacam pelo movimento: chegam trazendo mata, mar e sertáo, invadem, persistem, se juntam com orixás e espíritos desencarnados, vivem no leva e traz, desenhando territórios afetivos e arrastando consigo humanos, outras entidades, objetos. Definem seus próprios caminhos e ao fazê-lo multiplicam conexôes náo só entre tempos e lugares diferentes, mas entre práticas e formas de existir diferentes.

Para traçarmos as rotas dos caboclos e aos poucos desenharmos as cartografias de suas trajetórias, buscamos aqui acompanhar seu movimento e dos caboclos cria zonas de atração e performa uma topologia móvel, a partir da qual se abrem diferentes possibilidades de convivência. Essas características irão inevitavelmente nos escapar enquanto estivermos presos a uma concepçáo de movimento como mero deslocamento no espaço. 
É bem verdade que orixás também se conectam a humanos e a outros orixás por afinidades e afetos, produzindo aproximações e separações na dinâmica interna dos seus terreiros. Além disso, movimento e traçado de conexôes caracterizam também os modos de algumas entidades do panteão africano, em especial Exu. A questão aqui não é se apenas o caboclo detém essa propensão ao movimento e aos afetos. O que nos interessa ressaltar é que no movimento de quem chega, persiste, se junta e compóe, caboclos maximizam e estendem possibilidades de conexão e convivência, contribuindo para produzir arranjos variados nos terreiros e na vida das pessoas que são tocadas por eles.

\section{REFERÊNCIAS}

BANNAGIA, Gabriel. As Forças do Jarê: religiao de matriz afriacana na Chapada Diamantina. Rio de Janeiro, Garamond, 2015.

BASTIDE, Roger. As Religióes Africanas no Brasil: contribuição a uma sociologia das interpenetraçôes de civilizaçôes. São Paulo: Ed. Civilizaçôes, Livraria Pioneira Editora, 1985 [1960].

BASTIDE, Roger. O encontro entre deuses africanos e espíritos indígenas. In: BASTIDE. O Sagrado Selvagem e outros ensaios. São Paulo: Companhia das Letras. 2006 [1973].

CARNEIRO, Edison. Candomblés da Bahia. Rio de Janeiro: Ed. de Ouro, 1969 (1948).

FERREIRA, Almiro Miguel. Candomblé de Caboclo. In: Encontro das Nações de Candomblé. Salvador: Inamá e Universidade Federal da Bahia, 1984. FERRETI, Mundicarmo. Terra de Caboclos. São Luís: SECMA, 1994. LANDES, Ruth. A Cidade das Mulheres. Rio de Janeiro: Editora UFRJ, 2002 [1947]. 
PIERSON, Donald. Brancos e Prêtos na Bahia: estudo de contacto racial. São Paulo, Ed. Nacional, 1971 [1942].

QUERINO, Manuel. Costumes Africanos no Brasil. Rio de Janeiro: Civilização Brasileira, 1938 (1919).

RABELO, Miriam C.M. Play and Struggle: dimensions of the religious experience of peasants from Nova Redenção, Northeast Brazil. Tese de doutorado, Universidade de Liverpool, Reino Unido, 1990.

RABELO, Miriam C.M. Jarê Cult Centres and Eccesiastical Base Communities: the creation of identity among peasants in Nova Redenção, Northeast Brazil. In: ROSTAS, Susana; DROOGERS, André (orgs.). The Popular Use of Popular Religion in Brazil. Amsterdam: CEDLA, 1993 (p. 29-51).

RAMOS, Arthur. O Negro Brasileiro. Recife: Fundação Joaquim Nabuco, 1940 (1934).

RODRIGUES, Nina. Os Africanos no Brasil. Centro Edelstein de Pesquisas Sociais, Biblioteca Virtual de Ciências Humanas, 2010 (1938).

SANTOS, Jocélio Teles dos. O Dono da Terra: o caboclo nos candomblés da Bahia. Salvador: Editora Sarah Letras, 1995.

SENNA, Ronaldo. Jarê: manifestação religiosa na Chapada Diamantina. Tese de doutorado, Universidade de São Paulo, 1984.

Recebido em: 07/08/2020

Aprovado em: 03/09/2020 